NBER WORKING PAPER SERIES

\title{
SUPPLEMENTAL PLAN OFFERINGS AND RETIREMENT SAVING CHOICES: AN ANALYSIS OF NORTH CAROLINA SCHOOL DISTRICTS
}

\author{
Robert L. Clark \\ Emma Hanson \\ Melinda Sandler Morrill \\ Aditi Pathak \\ Working Paper 21382 \\ http://www.nber.org/papers/w21382 \\ NATIONAL BUREAU OF ECONOMIC RESEARCH \\ 1050 Massachusetts Avenue \\ Cambridge, MA 02138 \\ July 2015
}

This paper was prepared for the NBER Conference on Retirement and Health Benefits in the Public Sector, April 10-11, 2015, and the authors are grateful for comments from Brigitte Madrian and other conference participants. The authors thank Bryan Allard for excellent research assistance and Robert Hammond and Thayer Morrill for helpful comments and suggestions. The authors gratefully acknowledge the assistance of North Carolina State Treasurer Janet Cowell as well as Steve Toole, Mary Buonfiglio, and Sam Watts of the North Carolina Retirement Systems in obtaining the payroll data and administering the survey used in this study. The authors also gratefully acknowledge Adam Hooks at Education Management Systems and Mark Gooch of K12 Financial for modifying the school district payroll software to allow districts to provide payroll data. The TIAA CREF Institute provided funding for this research. The views expressed herein are those of the authors and do not necessarily reflect the views of the National Bureau of Economic Research.

At least one co-author has disclosed a financial relationship of potential relevance for this research. Further information is available online at http://www.nber.org/papers/w21382.ack

NBER working papers are circulated for discussion and comment purposes. They have not been peerreviewed or been subject to the review by the NBER Board of Directors that accompanies official NBER publications.

(C) 2015 by Robert L. Clark, Emma Hanson, Melinda Sandler Morrill, and Aditi Pathak. All rights reserved. Short sections of text, not to exceed two paragraphs, may be quoted without explicit permission provided that full credit, including (C) notice, is given to the source. 
Supplemental Plan Offerings and Retirement Saving Choices: An Analysis of North Carolina School Districts

Robert L. Clark, Emma Hanson, Melinda Sandler Morrill, and Aditi Pathak

NBER Working Paper No. 21382

July 2015

JEL No. H75,J26,J45

\begin{abstract}
Unlike private sector employers, public school districts generally offer more than one type of supplemental retirement savings plan and allow multiple vendors to offer products. Using individual-level payroll data from over half of the public school districts in North Carolina coupled with data from an employer survey, this study examines the impact of inter-district differences in supplemental plan administration on participation in these savings vehicles. We find wide variation in total participation rates and in 403(b) plan participation rates in particular, even among this population of public-sector workers with the same defined benefit pension plan, health plan, and retiree health coverage. Individual and district characteristics explain some, but not all, of the variation observed.
\end{abstract}

Robert L. Clark

Poole College of Management

Box 7229

North Carolina State University

Raleigh, NC 27695

and NBER

robert_clark@ncsu.edu

Emma Hanson

North Carolina Department of State Treasurer

Retirement Systems Division

3200 Atlantic Avenue

Raleigh, NC 27604

and North Carolina State University

Emma.Hanson@nctreasurer.com
Melinda Sandler Morrill

Department of Economics

North Carolina State University

Box 8110

Raleigh, NC 27695-8110

melinda_morrill@ncsu.edu

Aditi Pathak

Department of Economics

North Carolina State University

Raleigh, NC 27695-8110

aspathak@ncsu.edu

A data appendix is available at:

http://www.nber.org/data-appendix/w21382 


\title{
Supplemental Plan Offerings and Retirement Saving Choices: \\ An Analysis of North Carolina School Districts
}

\author{
"Historically, the 403(b) market has been thought of as the Wild West of retirement savings \\ plans, ” Mercado (2014).
}

While examining 401(k) plans has offered considerable insight into private sector employees' retirement saving, much less is known about saving in 403(b) plans, a related retirement saving plan option available to school district employees. ${ }^{1}$ In fact, the IRS tax code that extended 403(b) coverage to public education employees predates the code that created 401(k) plans by about 17 years (1961 and 1978, respectively). Even so, 403(b) plans have traditionally been subject to less oversight and scrutiny than the heavily-regulated $401(\mathrm{k})$ plans. $^{2}$ Mercado (2014) notes in an InvestmentNews article that the number of vendors and lack of oversight have created an environment where vendors charge high administration fees and offer investment options with high surrender charges. Writing in Kiplinger's Personal Finance, Lankford (2012) argues that the biggest differences between 401(k) and 403(b) plans are in plan management and marketing. She writes, "Instead of a menu of funds -- with easy

\footnotetext{
${ }^{1}$ For a comprehensive overview of savings in 401(k) plans and the effects of design features such as automatic enrollment and automatic escalation, see Choi, et al. (2002) and Choi, Laibson, and Madrian (2004).

${ }^{2}$ SigRist and Brown (2000) provide an overview of how differences in the regulatory environment have shaped private-sector 401(k) plans relative to public sector defined contribution plans.
} 
access to information about fees and performance -- many school systems just hand out a list of sales reps."

Despite this concern in the popular press, few systematic studies of 403(b) plans exist, in part due to the lack of large enough sample sizes in nationally-representative datasets. Nevertheless, the widely prevalent 403(b) plan plays an undeniable role in teachers' ultimate accumulation of retirement wealth, and the literature from the private sector may not be especially informative with regard to employee behaviors and the employer's impact on retirement savings in the case of public employees with access to 403(b) plans. ${ }^{3}$

Using survey data from 403(b) plan administrators merged with detailed administrative records from over half of all school districts in North Carolina, this study documents the variation in plan administration and offerings across districts and then explores the factors that predict individuals' plan participation. We consider whether employees in districts with many plans and vendors experience 'information overload' or whether diversity in offerings and marketing methods attracts more workers to participate in supplemental retirement saving plans.

Employer-provided supplemental retirement saving plans in the public sector differ from their counterparts in the private sector along several dimensions. In the private sector, employers generally provide a single tax-qualified defined contribution plan, such as the

\footnotetext{
${ }^{3}$ Beshears, et al. (2011) provide a discussion of how lessons learned from retirement saving in the private sector might be applied to the public sector.
} 
401(k), and participation is optional. In contrast, full-time employees of public employers are typically enrolled in a mandatory pension plan, usually a defined benefit plan (Clark, Craig, and Sabelhaus, 2011). Most public employers also offer one or more voluntarily supplemental retirement saving plans. Public education employers, in particular, can offer three different types of tax-deferred supplemental retirement plan- the 403(b) plan, the 457 plan, and, occasionally, the $401(\mathrm{k})$ plan. ${ }^{4}$ In addition, multiple vendors are often allowed to offer products to school district employees under these plans, whereas private-sector employers generally offer a 401(k) plan serviced by a single vendor. The fact that public employers can offer multiple retirement saving plans to their employees raises a number of important issues that have received little, if any, attention, since they do not arise in the private sector.

Findings on supplemental plan participation from the private sector might not apply in the public sector. It might be the case that workers in the public sector are simply different in their characteristics and preferences than employees in the private sector. Public employers may be providing different retirement saving plans in order to cater to these differences and target their workers' distinct preferences. Another possibility is that, given the level of guaranteed retirement income typically provided by defined benefit plans, the need for additional retirement saving is quantitatively or qualitatively different for public sector

\footnotetext{
${ }^{4}$ Public sector employers are only allowed to offer a 401(k) plan if the plan was established before May 1986. Appendix A compares the characteristics of the three plan types and their federal regulations.
} 
workers compared to the needs of most private sector employees, for whom the 401(k) plan is their only employer-provided retirement plan.

Workers who change jobs more frequently may not be able to take advantage of the value of a defined benefit plan. Obviously, not all school personnel will remain with the district or within the state for their entire career. As a result, the value of their defined benefit pension will be significantly lower compared to those who remain for their entire career. ${ }^{5}$ In addition, those teachers who have at least 30 years of service are eligible to retire at any age. Thus, some retirees can expect to spend 30 or more years in retirement. Younger retirement ages and longer periods spent in retirement mean that retirees are likely to need additional resources during their retirement years, particularly if the defined benefit pension does not increase with inflation or to accommodate an active lifestyle in the early years of retirement.

To shed light on the questions surrounding supplemental retirement saving in the public sector, this analysis focuses on how teachers and other school district personnel respond to the retirement saving options offered to them. North Carolina schools offer a useful setting for such an analysis because all of the employees are covered by the same defined benefit plan operated by the state, the same health plan, and the same retiree health plan. In contrast, there is

\footnotetext{
${ }^{5}$ Aldeman and Rotherham (2014) estimate that across all of the states the median proportion of teachers who remain on the job until they have vested in the mandatory pension is 45 percent with only 20 percent of teachers staying with the system until they attain the age of normal retirement specified in the plan.
} 
considerable variation across the districts in the supplemental retirement saving plan offerings and the management and oversight the district provides for these plans.

While all North Carolina school districts offer the state-managed NC 401(k) plan, districts vary in whether they offer the state-managed NC 457 plan and/or a district-managed 457 plan. All districts also offer a 403(b) plan, but the management and oversight of the vendors and vehicles offered under each district's 403(b) plan vary considerably. Thus, our analysis has the advantage of examining workers who are covered by the same mandatory pension plan, but who have access to a broad menu of supplemental retirement plan options that differs remarkably from district to district.

\section{RETIREMENT SAVING PLANS IN NORTH CAROLINA SCHOOL}

\section{DISTRICTS}

This study relies primarily on individual-level payroll records from March 2013

collected from more than half of the school districts in North Carolina. These data include basic economic and demographic information on school district employees, in addition to individual-level contributions to the supplemental plans offered in each district. The payroll data are merged with responses to a survey of each school district's Chief Finance Officer, Director of Business Operations, or Director of Human Resources. ${ }^{6}$ The survey asked for

\footnotetext{
${ }^{6}$ The survey was conducted in coordination with the North Carolina Department of State Treasurer, Retirement System Division (RSD). A link to the online survey was sent by the Director of the North Carolina Retirement Systems to all 115 school districts. Responses were received 90 of the 115 districts
} 
information on all retirement saving plans offered by each district, the management and oversight of these plans and vendors, as well as for information about any employer-provided communications and other informational efforts related to retirement plans. ${ }^{7}$ See Clark, et al. (2015) for detailed information about the data.

The richness of the combined individual- and district-level data allow us to investigate a number of questions concerning the influence of retirement plan management and the availability of retirement-related information on employee retirement saving behavior. Using this data set, we estimate the saving choices of teachers within and across school districts. Public school personnel in all school districts across North Carolina are enrolled in the Teachers' and State Employees' Retirement System (TSERS) and in the State Health Plan (SHP). ${ }^{8}$ TSERS and the SHP are broadly representative of pension and health plans available

between August 2013 and November 2013. Our research assistant spoke with staff at 79 of the districts to verify responses and aid in completing the survey.

${ }^{7}$ Additional data were gathered from districts' websites and other public sources to: (1) validate districts' survey responses, and (2) create an index of district website quality. ${ }^{8}$ TSERS provides a defined benefit plan with a formula of 1.82 percent per year of service times an average salary over the 4 highest years of earnings. Teachers are also covered by Social Security. Currently, all retiring teachers who were hired before October 1, 2006 and those hired after that date who retire with 20 or more years of service are eligible to enroll in a 70/30 retiree health plan without any premium. Retirees hired on or after October 1, 2006 with 10 to 19 years of service must pay 50 percent of the premium and those with 5 to 9 years can remain in the state plan but must pay the full premium. No subsidy is given for spousal or dependent coverage, although access is permitted. The retiree health plan is subject to change by the General Assembly. A summary of employee benefits is available at: http://www.ncleg.net/FiscalResearch/fiscal_briefs/Fiscal_Briefs_PDFs/Fiscal_Brief_Value_of_Emplo yee_Benefits.pdf, [accessed June 2015]. 
to teachers in other states. ${ }^{9}$ While most of the annual salary for school district personnel is paid by the state according to a fixed pay scale, most districts provide a local supplement to some employees' state-funded base salary. Average annual supplements for teachers vary from zero dollars in six districts to more than $\$ 6,000 .{ }^{10}$ Other employee benefits (e.g. vacation) and job requirements (e.g., number of work days and number of hours worked per day) are similar throughout North Carolina's school districts.

Historically, 403(b) retirement saving plans have been the most prevalent retirement saving plan available to teachers and other school district employees. ${ }^{11}$ In addition to district-managed 403(b) plans, school districts may offer state-managed 401(k) and 457 plans as well as district-managed 457 plans. ${ }^{12}$ Importantly, tax treatments differ for the various plans. There is a single combined annual contribution limit for 401(k) and 403(b) plans while

${ }^{9}$ Clark, Craig, and Sabelhaus (2011) compare state retirement plans for teachers and other state employees. In most regards, the North Carolina retirement has characteristics near the mean of state plans across the country. Clark and Morrill (2010) provide a detailed discussion of state health plans for teachers and state employees. The North Carolina plan has traditionally been one of the more generous retiree health plans but has recently undergone reforms which have increased eligibility requirements and for the first time imposed a premium on one of the plan offerings.

${ }^{10}$ The 2013 average supplement for teachers, principals, and assistant principals in each district are made publicly available through the North Carolina Department of Public Instruction: http://apps.schools.nc.gov/pls/apex/f?p=1:25:1259484044504001::NO::P25 SELECTYEAR:2014, [accessed June 2015]

${ }^{11}$ Scism (2012) reports in the Wall Street Journal that approximately three million elementary and secondary school employees had about $\$ 109$ billion in 403(b) plans as of 2010.

${ }^{12} \mathrm{NC} 401(\mathrm{k})$ and NC457 plans are managed by the RSD of the Department of State Treasurer. These plans are provided by a single vendor (Prudential), offer very similar investment options, and have the same marketing model. 
there is a separate limit on contributions for 457 plans. The similarity of these plans and their tax treatment raises the question of why a school district would want to spend resources to offer two or more saving plans.

Public employers must consider three important elements concerning retirement saving plans when deciding upon the number and type of retirement options to offer to their employees: (a) the type of tax-qualified saving plans to offer; (b) the number of vendors allowed to provide retirement plans and products to employees under each tax-qualified plan type offered; and (c) the extent of responsibility to assume in overseeing the plan(s) and in communicating information about the plans, vendors, and fees to district personnel. ${ }^{13}$

It should be noted that the plan offerings by districts often reflect the various objectives of school board members, influential employees within the district, and finance and human resource administrators charged with the day-to-day operations and administration of the district's plan(s) and product(s). ${ }^{14}$ Finance and business operations staff may be concerned about the time needed to oversee plans and the expertise necessary to develop and

\footnotetext{
${ }^{13}$ In the public sector, it is often unclear who is actually responsible for making decisions about each of these elements of public employers' retirement plans. In the case examined here, district administrative staff must manage retirement programs, but the local school boards typically make the final decisions. ${ }^{14}$ Scism (2012) summarizes the management of 403(b) plans across the country by noting: "Most districts, meanwhile, have taken a hands-off approach; in essence, the 403(b)s in many places are akin to individual retirement accounts." This is similar to our observation of districts in North Carolina. Many plan managers report that they consider it their job to give employees the opportunity to contribute to a plan, but do not believe that they have the authority or responsibility to regulate the vendors or specify the investments offered and the fees charge to participants.
} 
manage an optimal variety of plan types and vendors. Human resource staff may be concerned with the time and expertise required to select the most effective methods of communicating retirement plan information to employees, the time needed to develop such materials, and the expertise required to offer guidance to employees attempting to choose a supplemental retirement plan.

The neoclassical model of individual choice suggests that more plans and vendors will lead to higher participation rates, all else equal, since individuals are more likely to find a plan that suits them (i.e., is above their reservation price for purchasing). However, behavioral economics suggests two alternative scenarios. First, too many choices could lead to 'information overload. ${ }^{15}$ On the other hand, a new or particularly aggressive vendor might make the need to save more salient and increase participation in all plans. In this 'rational inattention' model, the advertising and promotional activities of one plan or vendor have a spillover effect such that participation increases overall. In a static environment, we are not able to provide a clean test between these hypotheses. However, we do consider the role of plan design, management, and oversight in employee participation in supplemental retirement

\footnotetext{
${ }^{15}$ Madrian and Shea (2001) and Choi, Laibson, and Madrian (2009) show that complex savings decisions discourage employees from participating in employer sponsored retirement plans. Iyengar, Huberman and Jiang (2004) find a drop in plan participation as the number of fund options rises. Agnew and Skyzman (2005) show that as investment options increase and choices become similar, employees face 'information overload' and may end up choosing the default option. Iyengar and Kamenica (2010) illustrate that access to more funds in a 401(k) plan is associated with individuals seeking a 'simpler' rather than less risky option (i.e., greater allocation to money market and bond funds rather than equity funds).
} 
saving plans.

We begin with an overview of plan design, management, and oversight. Table 1

presents district characteristics for the 90 districts that responded to our survey and for the 53

districts with payroll records that were successfully merged with survey responses. Columns

(2) and (3) provide payroll data at the district level and at the individual level, respectively. We use payroll records for 71,156 full-time employees in our analysis. ${ }^{16}$ Table 1 illustrates a wide variety of plan offerings, plan oversight, and management decisions.

\section{[Table 1]}

\section{A. Choice of Plan Types}

Historically, 403(b) plans have dominated the retirement plan market among school districts, possibly due to the 403(b) plan's comparatively more relaxed federal regulations governing plan sponsors and vendors or the fact that these plans were available to school personnel years prior to the availability of other forms of retirement saving plans. School administrators often have to decide whether to provide access to a district-managed 457 plan and whether to allow their employees to participate in state-managed $401(\mathrm{k})$ or 457 plans. State-managed $401(\mathrm{k})$ and 457 plans tend to be more closely monitored, have fewer vendors, and vendors are more likely to have been selected through a formal bidding process. Why and how school districts decide to adopt and manage alternative retirement saving plans is an

${ }^{16}$ Clark, et al. (2015) provides a detailed description of the data. 
interesting puzzle.

As shown in the first portion of Table 1, all school districts in our sample offer a 403(b) plan and the NC 401(k) plan - North Carolina's state-managed 401(k) retirement saving plan. Thus, all districts in our sample offer at least two plans. Further, 75 out of 90 (over 80 percent) of the districts allow their employees to select from at least 3 different retirement saving plans. Twenty-five of the 90 districts added the state-managed NC 457 plan within the past 5 years. ${ }^{17}$ Among the districts included in our individual-level analysis, the patterns are similar and indicate variation in plan offerings.

\section{B. Choice of Plan Characteristics and Oversight}

The management of 403(b) plans differs significantly from most 401(k) plans in both the public and private sectors in that multiple vendors are allowed and there are relatively fewer restrictions placed by the IRS on plan characteristics and vendor practices. ${ }^{18}$ In some states, the 403(b) plans are overseen at the state level, meaning that centralized state agencies are responsible for selecting, regulating, and overseeing the vendors approved to offer products in the local school districts' 403(b) plans within the state. In other states, local school districts are

\footnotetext{
${ }^{17}$ For the sample reported in Column (2), Table 1 of the 53 districts for which we have payroll data, the six districts that adopted NC 457 in 2008 or before each had less than 800 full-time employees in March 2013.

${ }^{18}$ The management and regulation of 403(b) plans varies substantially across the states and across school districts within states (Clark and Hanson, 2013). Some state-managed plans have a relatively small number of vendors while in other states' plans allow more than 50 vendors to offer 403(b) products to employees. Similarly, plans managed by individual school districts have a wide range in the number of vendors that are approved to offer 403(b) products to teachers.
} 
entirely responsible for managing their supplemental retirement saving plans. The benefit programs offered by state and local governmental employers are exempt from the participation, vesting, reporting, and fiduciary standards of ERISA. ${ }^{19}$

In addition to affecting employees' participation in retirement saving at the extensive margin, the degree of control the plan sponsor maintains over the plan is an important factor influencing wealth accumulation. Some school districts allow all interested vendors to offer 403(b) products, provided they meet certain specified criteria. This open access environment can result in a large number of vendors offering products to employees. Since each vendor offers numerous investment options, employees face the significant challenge of finding information on the providers and their investment options and comparing the differences between them. ${ }^{20}$ In such an open access environment with little district oversight, individual teachers and school district employees bear the burden of deciding which vendor among all of those approved to offer a 403(b) plan provides the best mixture of products, services, and fees. Of course, employers can reduce the informational cost by providing information directly to employees, such as an online comparison of fees and investment options, as discussed further

${ }^{19}$ ERISA section 4(b)(1) provides that Title I does not apply to any employee benefit plan that is a 'governmental plan' as defined in ERISA section 3(32).

${ }^{20}$ In California, teachers can choose from over 50 vendors with thousands of investment options. CalSTERS provides a useful website, 403bCompare, which provides information on investments and fees for vendors so that teachers can compare alternative products. However, the large number of vendors and options places a significant informational burden on teachers interested saving for retirement. 
below. Interestingly, only 8 out of the 90 districts that responded to the survey reported even attempting to obtain fee information from the 403(b) vendors that offer products to their employees. Although we do not have systematic evidence in this study, less oversight and no formal selection process typically results in vendors charging higher fees for the same products.

The management and oversight practices in North Carolina districts vary from being completely open access to highly controlled environments. Although we do not have information on the reasons why each district chose the management model in place, we can evaluate the associations between different management models on retirement saving plan participation. Among the districts responding to the survey, the 403(b) plans have between 1 and 13 different vendors. The modal structure of the 403(b) plans is to have between 3 and 5 vendors, which 39 out of 90 (or 43 percent) of the districts report having. Employers can limit the number of vendors through a competitive bidding process by issuing a solicitation such as a Request for Proposals (RFP), although very few school districts in North Carolina have done so. $^{21}$

In 2008, new IRS regulations were imposed that forced school districts to reevaluate their 403(b) offerings in an effort to meet the new standards. Districts began deselecting

\footnotetext{
${ }^{21}$ Our survey of district plan managers included a question on whether the district had issued an RFP for 403(b) vendors, with 11 responding in the affirmative. We believe this is an overestimate and that many respondents were confused by the question and responding affirmatively if they had issued an RFP for any type of vendor, not just 403(b) vendors.
} 
vendors that were not in compliance with the new rules. ${ }^{22}$ In personal interviews conducted by the authors, district plan administrators reported removing some 403(b) vendors from their plans because the vendors would not provide the information required under the new provisions. If a district recently removed several 403(b) vendors from their plan offerings, then new employees might find it less appealing to participate because of confusion or concerns over the future of 403(b) plan offerings.

Throughout our analysis, we classify districts in three ways based on the management and oversight of the 403(b) plans. First, if the district imposed any selection criteria beyond a minimum enrollment requirement, we classify them as selective. Only 32 of the 90 districts that responded to our survey had employed some criteria for selecting vendors beyond just a minimum number of enrollees; however, these selective districts employed almost 40 percent of employees. Note that participation and vendor count are mechanically related since most districts require minimum enrollments for vendors to be listed.

The second classification of oversight we consider is whether the district formally reviewed the selection criteria for 403(b) vendors within the last five years (39 out of 90 districts recently reviewed criteria). Finally, the third classification is whether the district

\footnotetext{
${ }^{22}$ Scism (2012) writes that the average school district now allows between 5 and 10 providers but this is down from 40 before the IRS rules were implemented. Deselecting vendors could take several forms. Vendors could be required to exit the plan and employees could be required to shift all funds to one of the remaining vendors. Alternatively, vendors could be prohibited from accepting new participants but could continue to service the accounts of their existing participants.
} 
reporting having evaluated their plan offerings. We find that 27 out of 90 districts reported having evaluated their plan offerings to determine whether significant changes needed to be made. Not surprisingly, there is a positive correlation between district size and the amount of oversight as captured by these measures. In summary, its seems clear that the management of school districts in North Carolina have devoted limited time and effort to the oversight of the supplemental retirement plans offered in their district.

\section{Choice of Promotional Activities}

Once a school district has determined the plan types and characteristics of the plans, the finance officer or human resource manager must decide how best to promote and advertise the plan offerings. One easy venue for disseminating retirement plan information is the district's website. We examined the websites of the school districts in North Carolina to determine what information is provided pertaining to the supplemental retirement plans. We evaluated the availability of key information concerning 403(b) plan vendors, investment options, fees, and methods of enrollment in the plan. As shown in the final rows of Table 1, we created three groups based on the quality of the website in terms of information about supplemental retirement saving plans: low (58 districts), moderate (17 districts), and high (15 districts). ${ }^{23}$

Although the websites sometimes contain information on all plan types, in general the marketing strategies for the local plans will differ from the state-managed plans. There are

${ }^{23}$ Clark, et al. (2015) provides more detail on the characteristics of the district websites. 
currently more than 150,000 active school system employees who are potential participants in at least one of the North Carolina state-administered plans. Prudential markets these plans primarily through e-mail and the plan website. ${ }^{24}$ These plans are coordinated through the North Carolina Retirement Systems, and account balances are available online and as part of employee's annual benefit statements.

In contrast, since each school district approves vendors for its locally administered 403(b) plan (and 457 plan, if any), vendors typically identify company representatives to be account managers for these local plans which cover only the school personnel in the district. The vendors' account managers are usually responsible for marketing the plan directly to employees through benefit fairs and personal communications. Sales representatives from approved 403(b) vendors arrange school visits and attend benefits fairs to provide information to teachers about their plans and enroll new participants. Both 403(b) vendors and Prudential provide retirement planning workshops. A team of financial advisors visits an employer, who hosts a 'retirement workshop' and encourages employees to visit during their work hours and learn about their retirement needs and plan offerings.

Thus, one important difference between the 403(b) plans and local 457 plans and the state-managed NC 401(k) and NC 457 plans appears to be the in-person element, whereby

\footnotetext{
${ }^{24}$ Prudential also targets employers as part of their marketing campaigns, providing similar materials to state and local governmental agencies participating in the plans to distribute to their employees on Prudential's behalf.
} 
sales representatives sell products directly to employees at school districts. We do not have systematic data on differences in marketing strategies across districts, so we cannot quantify the extent to which these differences predict plan choices and participation rates.

A final aspect of district management that we consider is whether the district provides contact information for the approved 403(b) vendors directly to employees or whether employees must obtain the information from a third party. Specifically, our survey asks whether school personnel can get the district's list of approved 403(b) vendors and vendor contact information directly from the district via the website, benefit fairs, payroll inserts, or by request from a school/district-level department. This is related to website quality because one criterion for being classified as having a 'high-quality' website is providing contact information for vendors directly on the website. But, here we are more specifically considering whether the district is providing information directly to employees. Of the 90 districts responding to the survey, 43 provide information directly to employees.

\section{SCHOOL DISTRICT EMPLOYEES' RETIREMENT SAVING DECISIONS}

North Carolina school district employees have the option to contribute to employer-sponsored tax-advantaged accounts, so they must make decisions about whether to participate and how much to contribute. ${ }^{25}$ One unique consideration of the retirement saving choices of school district employees is the decision regarding which retirement saving plan is

\footnotetext{
${ }^{25}$ The California Legislative Analyst's Office (2014) provides a detailed assessment of retirement saving plans available to teachers and other public employees.
} 
best for them among 403(b), 457, and 401(k) plan offerings. While the provisions and tax regulations of these plans are similar, there are differences that could make one plan more appealing to teachers with different career patterns or alternative financial needs and objectives. $^{26}$

The diversity in the management of 403(b) plans and the prospect of multiple-vendor plans influence the information costs that teachers must bear in order to determine the optimal choice of investments. The ability of school districts to offer $401(\mathrm{k})$ and 457 plans in additional to 403(b) plans only exacerbates the informational problem facing teachers. Thus, this study examines how various aspects of the plan offerings affect teacher saving decisions including the availability of the state-managed or a district-managed 457 plan, the number of 403(b) vendors, the amount of oversight of the 403(b) plans, the quality of the information provided by the district or state, and the fees charged by the vendors.

\section{A. Summary of Supplemental Plan Participation and Contribution Rates}

To begin, we present the average participation and contribution rates in each of the plan types for our sample. We focus here on our regression sample of 53 school districts and 71,156 employees (i.e., the merged payroll and survey data, as described in Section II). The first row of Table 2 shows that 32.0 percent of school district employees participate in any supplemental retirement saving plan. The most common supplemental type is the 403(b) plan, with 16.7

\footnotetext{
${ }^{26}$ Kilgour (2013) provides a detailed discussion of retirement benefit laws and programs.
} 
percent of employees participating in a 403(b), while 12.9 percent of employees participate in NC 401(k). In Table 2, we see that only about 1 percent of the sample participates in NC 457. This is somewhat surprising given that in Table 1, Column (3) we found that 37.8 percent of employees had access to NC 457. Similarly, almost 5 percent are participating in a locally-managed 457 plan. Only 4.6 percent of all employees participate in multiple plans. ${ }^{27}$

\section{[Table 2]}

We next consider contribution rates among school employees who participate in one of the supplemental plans. Conditional on participating, those in the 403(b) plan are contributing on average $\$ 150$ per month (about $\$ 1,800$ annually). Finally, we see that the average of the contribution rates in each of the plans is low, between 2 and 5 percent of salary. In results not shown, we find that over 93 percent of those contributing do so at a level that is less than 6 percent of salary. Similarly, almost 92 percent of active plan participants are contributing less than $\$ 2,000$ annually. We do not formally model contribution rates in the regression analysis for several reasons. First, we observe only one pay period, so cannot determine annual contributions for individuals that do not contribute an identical amount each pay period.

\footnotetext{
${ }^{27}$ This number might reflect strategic behavior among a small group of individuals (e.g., the most highly compensated, typically school superintendents and principals who are likely key policy decisionmakers). One reason why multiple plans might be offered is for highly compensated individuals to take advantage of the separate tax limits on contributions of 457 plans from 403(b) and 401(k) plans. We explore this further below.
} 
Second, even when conditioning on participation, contribution rates are not normally

distributed - rather, there is a low mean and a long right tail.

Figure 1 shows how the participation rate in any plan and, specifically, in the 403(b)

plan varies across the school districts. The proportion of district employees enrolled in any plan differs by about 40 percentage points from the lowest to the highest level while the rates for participation in the 403(b) plan vary by 30 percentage points. These are remarkably large differences when we consider that all of the districts are covered by the same defined benefit retirement plan (TSERS) and health plan and retiree health plan. ${ }^{28}$ In the subsequent subsections, we explore reasons for these large differences across districts.

\section{[Figure 1]}

\section{B. Participation in Retirement Saving Plans by School Personnel in North Carolina}

We now consider how individual characteristics are related to supplemental plan participation by estimating a series of participation regressions. Table 3, Column 1 presents the results from estimating whether the employee contributes to any supplemental retirement plan offered by the district. ${ }^{29}$ The proportion of school employees that contribute to any saving plan is 32.0 percent. Table 3 , Column 2 reports the estimated marginal effects from a Probit regression on the probability that a worker will be contributing to a 403(b) plan (mean of the

\footnotetext{
${ }^{28}$ One can predict how much variation is expected across districts due to random noise. Appendix B explores this 'counterfactual' exercise and illustrates that the observed level of variation is indeed higher than what would be anticipated from random noise.

${ }^{29}$ Means of the full sample are presented in Appendix Table C1.
} 
dependent variable is 16.7 percent). Column 3 repeats this analysis but only for workers that are contributing to any plan. The proportion of those contributing to a 403(b) plan among those who are participating in any plan is 52.2 percent. The estimates presented in Table 3 include a district fixed effect that should control for all district-level characteristics. In results not shown, estimated marginal effects in all three models are nearly identical when the district fixed effects are excluded. All regression models are estimated with a Probit, and marginal effects calculated at the mean are presented with standard errors clustered by district in parentheses.

\section{[Table 3]}

First, controlling for salary and tenure, participation rates decline with age both in any plan and in the 403(b) plan in particular. ${ }^{30}$ In general, individuals with higher annual earnings and longer tenures are expected to be more likely to contribute to retirement saving plans. Unfortunately, salary appears to be measured with considerable noise, particularly for the highest earners. $^{31}$ Tenure is determined based on the date of hire at a particular school district,

\footnotetext{
${ }^{30}$ Note that due to concerns over both measurement error and collinearity, we chose not to present results that included job classification in this regression. Results are similar when the three job categories (managers, instructional staff, and support staff) are controlled for.

${ }^{31}$ Many districts provide a local salary supplement, which may be paid monthly, annually, or in two installments with the payment frequency and month of payment differing among districts. Second, employees on a 10 or 11 month contract can choose to be paid over those months or over 12 months, and the data do not report pay-out period. The pay frequency variable that is included is simply bi-weekly versus monthly pay period. Finally, longevity pay, irregular pay and non-recurring income are only observed for the month of March.
} 
so previous employment tenure in another district is not considered. ${ }^{32}$ Participation rates overall, and in 403(b) in particular, are quadratic in both salary and tenure, although the 'turning points' are quite low ( $\$ 65,000$ annual earnings and 2.2 years of service for participation in any plan). These results should be interpreted with caution since, as Clark, et al. (2015) describe in detail, salary is understated in our data.

There are several interesting differences by racial/ethnic group, gender, and marital status. In Column (1), Table 3, we find that Hispanics are 3 percentage points less likely to be participating in any plan while those categorized as other racial/ethnic group are about 3 percentage points more likely to be participating relative to non-Hispanic whites. But, among those participating in any plan, non-Hispanic black workers are 8.6 percentage points more likely than non-Hispanic whites to be contributing to a 403(b) plan, holding constant salary. Both married and single men are less likely to be contributing to a saving plan compared to married women, 3.0 and 2.5 percentage points respectively. ${ }^{33}$ On the other hand, single females are 2.2 percentage points more likely to contribute to one of these plans than married women. Among participants, both unmarried males and females are more likely to be participating in a 403(b) plan. Since contributions to 403(b) plans are grouped with

\footnotetext{
32 In Clark, et al. (2015), a comparison to the TSERS actuarial report in 2013 finds that the distribution of tenure is roughly consistent with the aggregate statistics provided by the retirement system. Thus, we believe that tenure is measured reasonably well in our data.

${ }^{33}$ This finding is consistent with Huberman, Iyengar, and Jiang (2007) who study 647 DC pension plans and find that women are significantly more likely to participate than men. As described in footnote 31 , marital status is under-reported in the data.
} 
contributions to $401(\mathrm{k})$ plans for IRS tax purposes, while contributions to 457 plans are counted separately, the findings in Column (3) of Table 3 are consistent with married individuals strategically participating in 457 plans to maximize contributions. However, we see very few individuals contributing at levels at or near the IRS maximum limits.

To determine how important individual characteristics are in explaining cross-district variation in participation rates, we calculate the deviation from model predictions by capturing the residual of the actual participation rate minus the predicted participation rate generated from the regression reported in Table 3, Column (1) except without district fixed effects. We then aggregate these individual residuals to the district-level. These means of residuals by district are plotted in Figure 2 in ascending order of district population size. ${ }^{34}$ While the predicted and actual participation rates are quite similar for many districts, the lowest participation rate district has a nearly -0.2 residual while the highest participation rate district has nearly a positive 0.2 residual. Thus, there remains about a 40 percentage point spread between the participation rates of districts, even when adjusting the means for a host of individual demographic characteristics.

\section{[Figure 2]}

\section{District Characteristics}

Since all employees in all of the districts are covered by the same state retirement plan,

\footnotetext{
${ }^{34}$ Appendix B uses the regression equation to adjust participation rates and provides evidence that the variation observed is far above what might be expected from random noise.
} 
the same state health plan, and the same state managed retiree health plan, these large differences across the districts cannot be explained by these factors. Thus, we now examine what other factors might explain the variation in participation rates across the school districts. First, there are unobserved (to the researchers) differences in the underlying population in terms of propensity to save, along with individual-level heterogeneity in desire/need to save that is unmeasured in the data (e.g., spouse's income or financial literacy). ${ }^{35}$ These unobserved characteristics might be correlated with district plan offerings and plan management if districts respond to the requests and preferences of their workers, or it might be that district offerings affect individuals differentially in ways that the district fixed effects cannot capture.

Differences might also be due to peer effects or the effects of an influential school leader, as discussed further below. ${ }^{36}$

An interesting conjecture is that district management and their oversight practices are an important determinant of the likelihood that employees in a particular district will enroll in the retirement saving plan. The participation equations are re-estimated with additional district variables added to the specification in an attempt to identify specific practices that might influence participation decisions. While we expect that district factors, such as management

\footnotetext{
${ }^{35}$ For an overview of how financial literacy and planning affects retirement readiness, see Lusardi and Mitchell $(2009,2014)$ and references therein.

${ }^{36}$ Duflo and Saez (2002) explore the role of peer effects in supplemental plan participation among employees at a large university. Our ability to test this is hindered by the fact that our data do not allow for the identification of a particular school within each school district.
} 
policies, play a major role in encouraging employees to contribute to supplemental retirement plans, the regression analysis does not uncover any robust systematic patterns with the measures of management differences used in this analysis.

An interesting policy question is whether school district employees are more likely to contribute to a retirement saving plan when there is a small or large number of vendors. As described above, the neoclassical model predicts more investment options leads to higher participation rates, all else equal. But, behavioral economics suggests that 'information overload' may lead to lower participation rates. On the other hand, 'rational inattention' suggests that more advertising and an emphasis on saving, in general, will lead to higher participation rates. An industry group report claims that more choice leads to higher participation, on average (Davis, et al, 2011). ${ }^{37}$ Academic studies find that in the 401(k) world information overload associated with a large number of vendors and investment options typically leads to lower participation rates (e.g., Brown, Liang, and Weisbenner, 2007; Iyengar, Huberman, and Jiang, 2004).

In Table 4, we present parallel regression estimates to Table 3, except here we have replaced the district fixed effects with certain district-level characteristics. Note that individual-level demographics reported in Table 3 (but not district fixed effects) are also

\footnotetext{
${ }^{37}$ This report was published by the ASPPA Pension Education and Research Foundation. In sharp contrast, Vanguard (2003) finds that more choice reduces participation in retirement saving plans.
} 
included in the regressions in Table 4, but are not reported in the table. ${ }^{38}$

\section{[Table 4]}

First, we see that working in a district that has more 403(b) vendors is positively related to participation in any plan but not to 403(b) plans in particular. ${ }^{39}$ Together these findings are somewhat puzzling. While we had hypothesized that many vendors or many plan offerings would lead to information overload, more choices in vendors leads to higher total participation rates. The neoclassical model would suggest that more 403(b) vendors would lead to higher participation rates in $403(\mathrm{~b})$ plans but this direct effect of multiple vendors is not supported by the analysis. However, consistent with our findings, the behavioral model of 'rational inattention' suggests that more vendors, and the associated marketing activities, will increase supplemental plan participation rates in general even if individuals do not sign up with the marginal vendor. ${ }^{40}$

When considering participation in any plan, the estimated marginal effects of a district offering 3-5 403(b) vendors and on a districting offering 6 or more vendors are both 6.6 percentage points and are statistically significant. While the signs of the estimated marginal

\footnotetext{
${ }^{38}$ Many of our measures of management and oversight are likely collinear and all are measured with considerable error, thus any lack of statistical significance might reflect Type II error and insufficient power.

${ }^{39}$ The current measure of the number of vendors is from the survey and indicates the number of vendors that are allowed to enroll new members.

${ }^{40}$ One possible mechanism is that having a greater number of 403(b) vendors has a positive effect in getting workers interested in retirement saving, but, having reviewed all options, employees move away from the multi-vendor 403(b) plans and toward the single vendor state-managed plans.
} 
effects in columns (2) and (3) are positive, none are statistically significant. We show in Column (3) that, among participants, the existence of a local 457 plan reduces the probability of being in a 403(b) plan, suggesting that at least some of the employees view local 457 plans as substitutes for $403(\mathrm{~b})$ plans. $^{41}$

We find that districts that are more selective in allowing 403(b) vendors (i.e., impose more than a minimum enrollment criteria) have higher participation rates in any supplemental plan. However, again selectivity does not predict 403(b) participation in particular. It might be that districts whose population is more interested in supplemental plans invest more time and resources into managing and promoting plans. The estimated marginal effects of having evaluated 403(b) plan offerings are not statistically significant in all three regression models. Conditional on participating in any plan, individuals working in districts that have reviewed the criteria for 403(b) vendors within the past 5 years are more likely to be participating in the 403(b) plan, although total participation rates are not higher.

The effect of website quality is non-monotonic. In Table 4, Column (1) we see that moderate website quality is associated with significantly higher probabilities of participating in any plan and in 403(b) plans. Moderate quality websites provide some basic information on plan offerings but no contact information. On the other hand, high website quality is associated

\footnotetext{
${ }^{41}$ Interestingly, offering NC 457, and even having adopted NC 457 in the past 5 years, is not significantly related to overall plan participation. Recall that in Table 2 we observed very few employees contributing to NC 457.
} 
with significantly lower 403(b) plan participation in total and among participants. One explanation is that high -quality websites provide more detail on the product offerings (and sometimes on fees) and retirement planning information, and so make more transparent that 403(b) plans are not superior to the state-managed 401(k) or 457 plan. Alternatively, it could be that the highest quality websites are those that are newly revised so that most individuals in the data made their decisions about participation based while the website was of inferior quality. ${ }^{42}$ Furthermore, districts that have low participation rates might respond by revamping their websites. In this analysis, there are no longer negative effects of high -quality websites, but that high -quality websites only predict total participation. Thus, we find some support for both theories on website quality.

Interestingly, districts providing information directly to employees does encourage participation, especially in 403(b) plans. Note that this measure does not include promotional materials provided at orientation. Finally, while the probability of participation is lower in larger districts, participants in those large districts are more likely to be in 403(b) plans. It might be that 403(b) vendors are more attentive to a larger pool of potential customers.

\section{Job Categories}

Using information in the payroll records on job classifications, we group school

\footnotetext{
${ }^{42}$ To test between these alternatives, Appendix Table C. 2 presents parallel estimates to Table 4 for the sample of individuals hired in the past 2 years only. We find only weak evidence in favor of this explanation. We thank Brigitte Madrian for this useful suggestion.
} 
district employees into the following job categories: (1) managers, (2) instructional staff, and (3) support staff. The management category includes district leadership, principals, and assistant principals, but also anyone in a management role such as the cafeteria staff supervisor or front office manager. Table 5 presents statistics on participation and contribution rates for the full sample and then by job category. Several interesting patterns emerge. First, as one would expect, those in management positions earn more and are participating in a retirement saving plan at substantially higher rates than other school employees. On average, support staff are older, are earning lower salaries, and have the lowest rates of participation. We see that the 403(b) plans are relatively more popular among instructional staff. Interestingly, managers (who themselves may have influenced plan offerings) are substantially more likely to be participating in multiple plans.

\section{[Table 5]}

When considering contribution rates, we see that among those participating, managers are contributing at higher rates. While less than 1 percent of support staff and only about 1.29 percent of instructional staff are contributing at levels near the IRS maximum, about 3.53 percent of managers are contributing at least $\$ 15,000$ annually to either a 457 plan or combined in 401(k) and 403(b) plans. At the bottom of Table 5 we see that not only are managers and instructional staff contributing more money than support staff, but they are also contributing a higher fraction of their salaries. 


\section{DISCUSSION AND CONCLUSIONS}

Public school teachers are like many other American workers - they need to save for retirement. Retirement saving through tax-qualified, employer-provided plans is one of the most effective methods of accumulating resources to provide sustainable income during retirement. The options available to K-12 school personnel differ substantially from the 401(k)-dominated retirement saving environment in the private sector. First, the traditional retirement saving vehicle for public schools has been the 403(b) plan; however, school districts can, and often do, offer state- and/or district-managed 401(k) and 457 plans alongside their 403(b) options. Thus, the typical public school district employee might have to select from among several distinct tax-qualified retirement saving vehicles - a choice that most private-sector employees do not need to make.

The management of 403(b) plans by school districts varies considerably across states and across school districts within each state. School boards and district administrators are responsible for overseeing a number of important elements of their supplemental retirement plans, including the number of vendors allowed to offer retirement savings products to district employees, the vendor selection process, the restrictions on investment options offered and on fees charged by participating vendors, and the manner in which, as well as the extent to which, school districts communicate information about their retirement plan(s) to district employees. In many cases, employees who choose to enroll in the 403(b) plan must decide on their 
preferred vendor. After selecting the vendor, the individual then must select the desired investments for their retirement saving. Without considerable employer oversight, the cost of identical investments can vary greatly across vendors.

This paper examines retirement saving plans among school districts in North Carolina. Using individual-level data from payroll records merged with district-level characteristics from a survey, we estimate the probability of contributing to any supplemental plan and then focus specifically on participation in 403(b) plans. The probability of participating is quadratic in both salary and tenure. Women and non-Hispanic black workers have higher probabilities of contributing to a retirement saving plan and to a 403(b) plan in particular, all else equal. Among participants, non-married individuals are more likely to choose 403(b) plans than are married individuals. The estimated marginal effects of the demographic characteristics do not change qualitatively when district fixed effects are included, suggesting that these patterns are not driven by differential selection of certain types of workers to districts with different offerings. Considering the residuals from the regression on individual characteristics, we illustrate that participation varies significantly across the districts, holding constant individual characteristics and state benefits that are common to all school personnel. These differences may reflect unobserved population characteristics or the effects of peers or school leadership. Regressions estimating the probability of participation that include district characteristics provide evidence that having more vendors in the 403(b) plan is associated with higher 
participation rates in any plan. Plans with many vendors may draw more people in through providing greater choice, more tailored products, and greater marketing efforts. However, this process could also result in lower quality product offerings, potential 'information overload,' and less transparent fees. Clark and Richardson (2010) show that plans with fewer providers reduce administrative requirements and allow the plan sponsor to monitor the providers' products more effectively.

District-managed 457 plans appear to be substitutes for 403(b) plans among participants. In districts with highly selective 403(b) vendor restrictions, we observe higher rates of participation across all supplemental plans, but not higher participation rates in 403(b) plans, suggesting that district practices might reflect interest from employees. Moderate website quality, as proxied by whether the districts advertise the plans at all, is associated with higher participation rates, but high website quality (providing information on investment options) is associated with lower rates of participation in 403(b) plans. Still, even with these detailed control variables for district plan management and oversight activities, much of the variation across districts in participation rates is left unexplained.

This study contributes to the literature on retirement saving plan participation in the following ways. Few studies have looked at public-sector supplemental retirement savings plans, and even fewer have studied the 403(b) plan in particular. Because of the differences in retirement plan design, choices, and offerings in the public sector compared to the private 
sector, research from case studies of retirement saving behaviors in primary defined contribution plans in the private sector may not apply to this population of workers or their employers. Moreover, this study incorporates data from many different public-sector employers with a similar population of workers who share retirement benefits, health benefits, retiree health benefits, and similar salary schedules.

Future work should consider how product offerings and fees directly affect not only participation and contribution rates but also retirement wealth accumulation. Choi, Laibson, and Madrian (2010) find in an experimental setting that subjects 'overwhelmingly fail' at the goal of minimizing index fund fees even when fees are made more salient. This suggests that while fee transparency and the availability of information might have some impact on the retirement saving decisions of public employees, access to high quality supplemental plans will likely improve wealth accumulation for participants but will not necessarily draw individuals into saving. Supplemental retirement saving plans with high levels of oversight, whether state-managed or locally-managed, could improve the welfare of public employees who choose to participate through lower fees and greater retirement wealth accumulation. However, increased oversight at the district level typically demands that employers offer fewer saving options, which might also result in lower participation rates among school district employees. 


\section{REFERENCES}

Aldeman, Chad and Andrew Rotherham. 2014. 'Friends without Benefits: How States

Systematically Shortchange Teachers' Retirement and Threaten Their Retirement Security.'

http://www.teacherpensions.org/sites/default/files/Bellwether_PensionPaper 070814

$\underline{\text { Web.pdf }}$

Agnew, Julie R. and Lisa R. Szykman, 2005, 'Asset Allocation and Information Overload: The Influence of Information Display, Asset Choice, and Investor Experience,' Journal of Behavioral Finance, 6 (2): 57-70.

Beshears, John, James Choi, David Laibson, and Brigitte Madrian. 2011. 'Behavior Economics Perspectives on Public Sector Pension Plans,' Journal of Pension Economics and Finance, 10(2): 315-336.

Brown, Jeffery, Nellie Liang, and Scott Weisbenner. 2007. 'Individual Account Investment Options and Portfolio Choice: Behavioral Lessons from 401(k) Plans,' Journal of Public Economics, 91(10): 1992-2013.

California Legislative Analyst's Office. 2014. 'Analysis of Supplement Saving Plans for Educators.'

California State Teachers' Retirement System. '403b Compare'. https://www.403bcompare.com/

Choi, James, David Laibson, and Brigitte Madrian. 2004. 'Plan design and 401(k) savings outcomes,' National Tax Journal 57:275-298.

Choi, James, David Laibson, and Brigitte Madrian. 2009. 'Reducing the complexity costs of 401(k) participation: the case of quick enrollment D.A. Wise (Ed.), Developments in the Economics of Aging, University of Chicago Press, Chicago (2009), pp. 57-82.

Choi, James, David Laibson, and Brigitte Madrian. 2010. 'Why Does the Law of One Price Fail? An Experiment on Index Mutual Funds,' The Review of Financial Studies, 23(4): 1405-1432.

Choi, James, David Laibson, Brigitte Madrian, and Andrew Metrick. 2002. 'Defined contribution pensions: plan rules, participation decisions, and the path of least resistance.' In James Poterba (ed) Tax policy and the economy. MIT, pp 67-113 
Clark, Robert, Lee Craig, and John Sabelhaus. 2011. State and Local Retirement Plans in the United States, Cheltenham, UK, Edward Elgar.

Clark, Robert and Emma Hanson. 2013. 403(b) Plans for Public School Teachers: How They Are Monitored and Regulated In Each State? TIAA-CREF Research Dialogue, Issue No. 107.

https://www.tiaa-crefinstitute.org/public/pdf/institute/research/dialogue/107b.pdf

Clark, Robert, Emma Hanson, Melinda Morrill, and Aditi Pathak. 2015. 'Introduction of State Managed 403(b) Plan in North Carolina: Phase I Research Methods and Data,' North Carolina State University, Unpublished Manuscript, June 2015.

Clark, Robert and Melinda Morrill. 2010. Retiree Health Plans in the Public Sector: Is There a Funding Crisis? Cheltenham, UK, Edward Elgar.

Clark, Robert and David Richardson. 2010. 'Who's Watching the Door? How Controlling Provider Access Can Improve K-12 Teacher Retirement Outcomes.' TIAA-CREF Research Dialogue. https://www.tiaa-crefinstitute.org/public/institute/research/dialogue/rd_98.html

Davis, Debra, Geralyn Miller and Judy Miller. 2011. 'PROTECTING PARTICIPATION: The Impact of Reduced Choice on Participation by School District Employees in 403(b) Plans,' ASPPA Pension Education and Research Foundation. http://www.asppa.net/document-vault/pdfs/mediaroom/PERF_ResearchProtectingPart icipation2011.pdf.aspx

Duflo, Esther, and Emmanuel Saez. 2002. 'Participation and Investment Decisions in a Retirement Plan: The Influence of colleagues' choices,' Journal of Public Economics, 85: 121-148.

Huberman, Gur, Sheena Iyengar, and Wei Jiang. 2007. 'Defined Contribution Pension Plans: Determinants of Participation and Contributions Rates,' Journal of Financial Services Research, 31(1): 1-32.

Iyengar, Sheena, Gur Huberman and Wei Jiang. 2004. 'How Much Choice Is Too Much?: Contributions to 401(k) Retirement Plans,' in Olivia Mitchell and Stephen Utkus (eds.), Pension Design and Structure: New Lessons from Behavioral Finance, Oxford University Press, 83-95.

Iyengar Sheena and Kamenica E. 2010. 'Choice proliferation, simplicity seeking, and asset allocation' Journal of Public Economics, 94(7-8): 530-539. 
Kilgour, John G. 2013. 'Why Are Retirement Benefits in the United States So Complicated?: An Overview of How We Got Here,' Compensation \& Benefits Review, 45: 34-39.

Lankford, Kimberly (2012). 'Fighting for a Better 403(b).' Kiplinger 's Personal Finance, July 2012: 46-48.

Lusardi, Annamaria and Olivia Mitchell. 2009. 'How Ordinary Consumers Make Complex Economic Decisions: Financial Literacy and Retirement Readiness,' NBER Working Paper \#15350, September 2009.

Lusardi, Annamaria and Olivia Mitchell. 2014. 'The Economic Importance of Financial Literacy: Theory and Evidence,' Journal of Economic Literature, 52 (1); 5-44.

Madrian, Brigitte, and Dennis F. Shea. 2001. The power of suggestion: Inertia in 401(k) participation and savings behavior. Quarterly Journal of Economics 116 (4): 1149-87.

Mercado, Darla. 2014. 'Surrender fees haunt legacy 403(b) plans,' InvestmentNews, July 23. http://www.investmentnews.com/article/20140723/FREE/140729974/surrender-fees-h aunt-legacy-403-b-plans, [Accessed March 13, 2015].

Scism, Leslie. 2012. 'Teachers' 403(b) Plans See Big Changes,' The Wall Street Journal, January 9. http://www.wsj.com/articles/SB10001424052970204190504577039912581388668, [Accessed March 13, 2015]

SigRist, Kevin and Steward Brown. 2000. 'Design Considerations for Large Public Sector Defined Contribution Plans,' Financial Services Review 9:197-218.

Vanguard Center for Retirement Research. 2003. 'Can There Be Too Much Choice in a Retirement Saving Plans,' http://403bwise.com/pdf/vcrr choice study.pdf 
Figure 1. Participation Rates by District

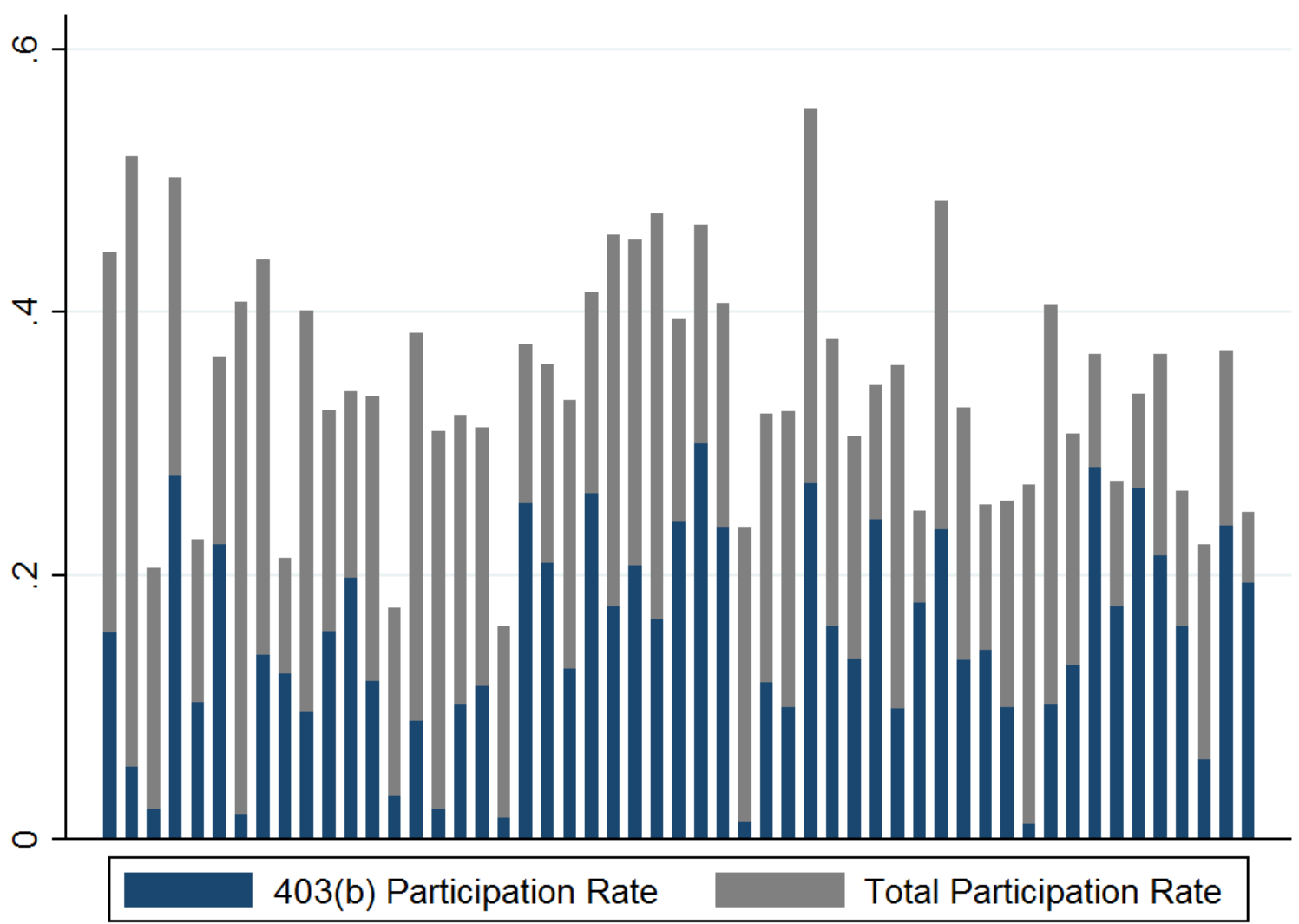

Notes: Each bar represents a district ordered by smallest to largest district by number of employees. The vertical axis is participation rate in any supplemental plan at the district level. 
Figure 2. Residuals Controlling for Individual Characteristics

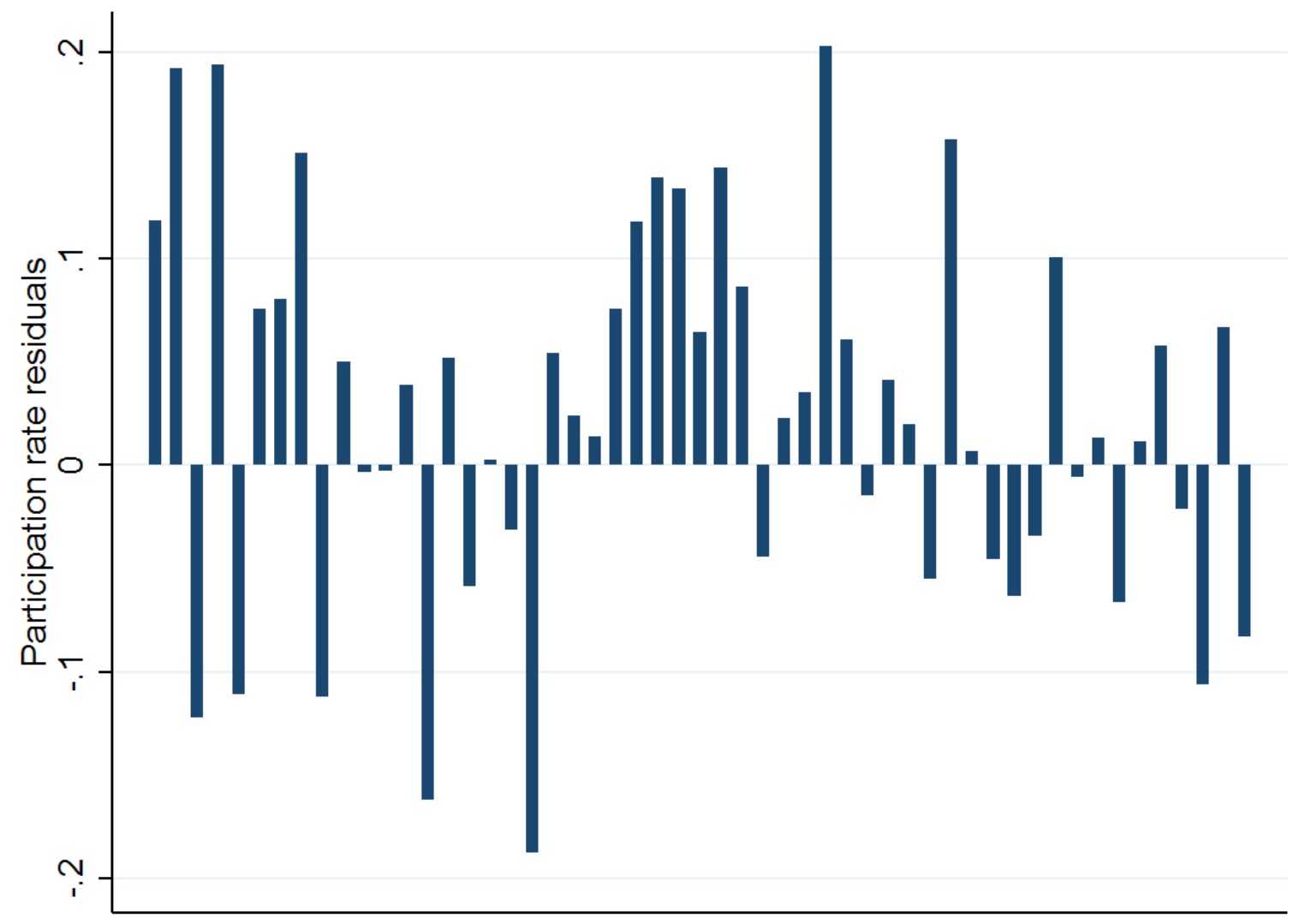

Notes: Each bar represents a district ordered by smallest to largest district by number of employees. The vertical axis is the residual participation rate in any supplemental plan at the district level, where the residual is calculated as the difference between the actual and predicted total participation rate. Predicted values are calculated from the regression of participation in any plan on individual characteristics, as in Table 3, Column 1, except without district fixed effects. 
Table 1. Sample Means and Descriptive Statistics

\begin{tabular}{|c|c|c|c|}
\hline & \multirow[b]{2}{*}{ (1) } & \\
\hline & & (2) & (3) \\
\hline & & & Districts Means \\
\hline & & & Weighted by \\
\hline & Districts Means & Districts Means & Number of \\
\hline Description of Data: & Survey Sample & Payroll Sample & Employees \\
\hline
\end{tabular}

School Districts

90

53

53

Number of Individuals

71,156

Number of Plans:

2

3

15 districts

5 districts

$5.8 \%$

50 districts

35 districts

$65.2 \%$

4

25 districts

13 districts

$29.0 \%$

Offers NC 457

38 districts

21 districts

$37.8 \%$

Offers Local 457

63 districts

40 districts

$85.5 \%$

Adopted NC $457 \mathrm{w} /$ in last 5 years

25 districts

15 districts

$32.8 \%$

Average Number of Vendors

4.17

4.15

5.95

Number of 403(b) Vendors

$1-2$

3-5

25 districts

15 districts

$16.4 \%$

6 or more

39 districts

22 districts

$27.0 \%$

26 districts

16 districts

$56.6 \%$

Selective

32 districts

18 districts

$39.9 \%$

Reviewed Criteria w/in last 5 years

39 districts

20 districts

$37.4 \%$

Evaluate Plans

27 districts

12 districts

$44.7 \%$

Attempted to obtain fee information

8 districts

3 districts

$11.0 \%$

Website Score

Low

58 districts

35 districts

$47.3 \%$

Moderate

17 districts

9 districts

$33.0 \%$

High

15 districts

9 districts

$19.7 \%$

District Provides Direct Information

43 districts

26 districts

$77.5 \%$

Notes: Numbers in italics are the count of districts that fall into each category. Data are gathered from the district survey. Columns 2 and 3 restrict the sample to districts that provided payroll data, with population weights applied in column 3 using employment levels from the payroll data. 
Table 2. Mean Participation and Contribution Rates

Source of Data:

Payroll Records + Survey

School Districts

Number of Individuals

71,156

Participation Rates

Total $32.0 \%$

403(b)

$16.7 \%$

$\mathrm{NC} 401(\mathrm{k})$

$12.9 \%$

NC 457

$1.3 \%$

Local 457

$4.7 \%$

Participates in multiple plans

$4.6 \%$

403(b) Participation among participants

$52.2 \%$

Contribution amounts among participants (Monthly)

403(b)

$\mathrm{NC} 401(\mathrm{k})$

$\$ 177$

$\mathrm{NC} 457$

Local 457

Contribution rate (\% of salary) among participants

\begin{tabular}{lc}
$403(\mathrm{~b})$ & $4.1 \%$ \\
$\mathrm{NC} 401(\mathrm{k})$ & $4.6 \%$ \\
$\mathrm{NC} 457$ & $2.1 \%$ \\
Local 457 & $4.3 \%$ \\
\hline
\end{tabular}

Notes: Data are from merged records from administrative data and district survey data for 53 school districts in North Carolina in March 2013. 
Table 3. Plan Participation, Individual Characteristics, and District Fixed Effects

\begin{tabular}{|c|c|c|c|}
\hline & Any Plan & 403(b) Plan & $\begin{array}{l}\text { 403(b) Plan } \\
\text { Participation }\end{array}$ \\
\hline & (1) & (2) & (3) \\
\hline \multirow[t]{2}{*}{$35-49.99$} & $-0.049 * * *$ & $-0.027 * * *$ & -0.015 \\
\hline & $(0.007)$ & $(0.006)$ & $(0.022)$ \\
\hline \multirow[t]{2}{*}{$50-54.99$} & $-0.079 * * *$ & $-0.045 * * *$ & -0.039 \\
\hline & $(0.011)$ & $(0.008)$ & $(0.034)$ \\
\hline \multirow[t]{2}{*}{55 and above } & $-0.116 * * *$ & $-0.051 * * *$ & -0.002 \\
\hline & $(0.009)$ & $(0.009)$ & $(0.039)$ \\
\hline \multirow[t]{2}{*}{ Annual Salary (1K) } & $0.013 * * *$ & $0.008 * * *$ & $0.004 * * *$ \\
\hline & $(0.002)$ & $(0.001)$ & $(0.001)$ \\
\hline \multirow[t]{2}{*}{ Annual Salary Squared } & $-0.0001 * * *$ & $-0.0001 * * *$ & $-0.0001 * * *$ \\
\hline & $(0.0000)$ & $(0.0000)$ & $(0.0000)$ \\
\hline \multirow[t]{2}{*}{ Tenure } & $0.039 * * *$ & $0.021 * * *$ & $0.009 * *$ \\
\hline & $(0.001)$ & $(0.001)$ & $(0.004)$ \\
\hline \multirow[t]{2}{*}{ Tenure Squared } & $-0.009 * * *$ & $-0.005 * * *$ & $-0.003 * *$ \\
\hline & $(0.000)$ & $(0.000)$ & $(0.001)$ \\
\hline \multirow[t]{2}{*}{ Black } & 0.016 & $0.033 * * *$ & $0.086 * * *$ \\
\hline & $(0.010)$ & $(0.006)$ & $(0.016)$ \\
\hline \multirow[t]{2}{*}{ Hispanic } & $-0.028 * *$ & -0.013 & -0.004 \\
\hline & $(0.013)$ & $(0.008)$ & $(0.021)$ \\
\hline \multirow[t]{2}{*}{ Other } & $0.026 * *$ & $0.017 * *$ & 0.013 \\
\hline & $(0.011)$ & $(0.009)$ & $(0.023)$ \\
\hline \multirow[t]{2}{*}{ Single Male } & $-0.025 * * *$ & -0.004 & $0.029 *$ \\
\hline & $(0.007)$ & $(0.005)$ & $(0.016)$ \\
\hline \multirow[t]{2}{*}{ Married Male } & $-0.030 * * *$ & $-0.016 * * *$ & -0.010 \\
\hline & $(0.006)$ & $(0.006)$ & $(0.018)$ \\
\hline \multirow[t]{2}{*}{ Single Female } & $0.022 * * *$ & $0.024 * * *$ & $0.050 * * *$ \\
\hline & $(0.004)$ & $(0.003)$ & $(0.008)$ \\
\hline Observations & 71,156 & 71,156 & 22,791 \\
\hline Mean Dependent Variable & 0.320 & 0.167 & 0.522 \\
\hline
\end{tabular}

Notes: Data are from payroll records. All models include district fixed effects. Marginal effects, calculated at the mean, are estimated from Probit regressions. Robust standard errors are in parentheses and are clustered at the district level.

$* * * \mathrm{p}<0.01, * * \mathrm{p}<0.05, * \mathrm{p}<0.1$. 
Table 4. Plan Participation and District Characteristics

\begin{tabular}{ccc} 
& 403(b) Plan Among \\
Any Plan & 403(b) Plan & Participants \\
\hline
\end{tabular}

Plan Offerings:

3-5 vendors

(1)

(2)

(3)

6 or more vendors

$0.066^{* *}$

0.051

0.071

(0.028)

(0.037)

(0.086)

$0.066^{* *}$

0.037

0.015

(0.032)

(0.035)

$(0.091)$

Offers NC 457

0.025

0.031

0.054

(0.032)

(0.031)

(0.063)

Offers Local 457

0.017

$-0.030$

$-0.115^{* *}$

(0.029)

(0.027)

$(0.054)$

Adopted NC 457 w/in 5 yrs

0.028

$-0.008$

$-0.057$

(0.033)

(0.029)

$(0.056)$

\section{District Oversight:}

Selective

$0.052 * *$

0.012

$-0.045$

(0.025)

(0.023)

(0.063)

Evaluate plan offerings

$-0.030$

$-0.030$

$-0.062$

(0.028)

(0.026)

$(0.078)$

Criteria reviewed w/in 5 years

$-0.028$

0.024

$0.103^{*}$

(0.027)

(0.023)

$(0.061)$

\section{District Information Provision:}

Moderate quality website

$$
0.114 * * *
$$

$0.071 * *$

0.050

(0.030)

(0.028)

(0.070)

High quality website

0.006

$-0.061 * *$

$-0.199 * *$

(0.029)

(0.027)

Directly Provide Information

0.002

$0.046^{* *}$

$0.135 * *$

District Size (in 00s)

$$
(0.025)
$$

(0.021)

(0.055)

$$
\begin{gathered}
-0.003 * * * \\
(0.001)
\end{gathered}
$$$$
-0.001
$$$$
0.003 *
$$$$
\text { (0.001) }
$$

Observations

71,156

71,156

22,791

Mean Dependent Variable

0.3203

0.1672

0.5220

Notes: Data are from payroll records merged with district survey responses. All models include individual characteristics reported in Table 3 but exclude district fixed effects. Marginal effects, calculated at the mean, are estimated from Probit regressions. Robust standard errors are in parentheses parentheses and are clustered at the district level. ${ }^{* *} \mathrm{p}<0.01,{ }^{* *} \mathrm{p}<0.05,{ }^{*} \mathrm{p}<0.1$. 


\section{Table 5. Participation and Contribution Rates by Job Category}

\begin{tabular}{|c|c|c|c|c|}
\hline & \\
\hline & Full Sample & Managers & Instructional & Support \\
\hline Number of Individuals & 71,156 & 2,156 & 55,925 & 13,022 \\
\hline Age & 46.06 & 49.20 & 44.75 & 51.17 \\
\hline Annual Salary & $\$ 34,624$ & $\$ 66,681$ & $\$ 35,119$ & $\$ 27,057$ \\
\hline \multicolumn{5}{|l|}{ Participation Rates } \\
\hline Total & $32.03 \%$ & $51.24 \%$ & $33.55 \%$ & $22.20 \%$ \\
\hline 403(b) & $16.72 \%$ & $22.77 \%$ & $17.98 \%$ & $10.27 \%$ \\
\hline $\mathrm{NC} 401(\mathrm{k})$ & $12.94 \%$ & $25.89 \%$ & $12.96 \%$ & $10.61 \%$ \\
\hline $\mathrm{NC} 457$ & $1.34 \%$ & $1.72 \%$ & $1.31 \%$ & $1.38 \%$ \\
\hline Local 457 & $4.68 \%$ & $7.46 \%$ & $5.07 \%$ & $2.51 \%$ \\
\hline Participates in multiple plans & $4.61 \%$ & $8.64 \%$ & $4.71 \%$ & $3.70 \%$ \\
\hline Among Participants: 403(b) Participation & $52.20 \%$ & $44.44 \%$ & $53.58 \%$ & $46.23 \%$ \\
\hline \multicolumn{5}{|l|}{ Contribution Rates Among Participants (Monthly) } \\
\hline 403(b) & $\$ 150$ & $\$ 241$ & $\$ 151$ & $\$ 107$ \\
\hline NC 401(k) & $\$ 177$ & $\$ 237$ & $\$ 182$ & $\$ 118$ \\
\hline $\mathrm{NC} 457$ & $\$ 72$ & $\$ 144$ & $\$ 74$ & $\$ 47$ \\
\hline Local 457 & $\$ 156$ & $\$ 263$ & $\$ 153$ & $\$ 130$ \\
\hline Contributes $15 \mathrm{k}^{*}$ in 457 plan $(\mathrm{s})$ or combined $401(\mathrm{k}) / 403(\mathrm{~b})$ & $1.31 \%$ & $3.53 \%$ & $1.29 \%$ & $0.59 \%$ \\
\hline \multicolumn{5}{|l|}{ Contribution rate (\% of salary) among participants } \\
\hline $403(b)$ & $4.09 \%$ & $4.04 \%$ & $4.13 \%$ & $3.83 \%$ \\
\hline NC 401(k) & $4.61 \%$ & $4.03 \%$ & $4.48 \%$ & $3.66 \%$ \\
\hline $\mathrm{NC} 457$ & $2.11 \%$ & $2.14 \%$ & $2.17 \%$ & $1.88 \%$ \\
\hline Local 457 & $4.33 \%$ & $4.71 \%$ & $4.29 \%$ & $4.52 \%$ \\
\hline
\end{tabular}

Notes: Data are from merged records from administrative data and district survey data for 53 school districts in North Carolina in March 2013. 


\section{APPENDIX A \\ Public Retirement Saving Plans}

Public employers have the option of offering alternative types of saving plans regulated under special tax codes. Both state and local governmental employers have the option of offering 457 plans. In addition, state governments may offer a state-managed 457 plan that local employers can allow their employees to join. States may also offer 401(k) plans that were grandfathered in before 1986 legislation, but no new 401(k) plans are allowed. ${ }^{43}$ Public schools, hospitals, and charitable organizations are allowed to offer 403 (b) plans. ${ }^{44}$ In some states, public school employees are considered state workers and are thus able to contribute to any available plans offered by their school district or the state government. ${ }^{45}$ All of these plans

${ }^{43}$ See the Tax Reform Act of 1986, which prohibited governmental employers from establishing new 401(k) plans. Governmental employers who had established 401(k) plans prior to the new legislation were allowed to continue offering these plans.

${ }^{44}$ A comparison of the provisions of the 401(k) and 457 plans offered by the state of North Carolina can be seen at https://www.nctreasurer.com/ret/401k\%20Plan\%20Features/PlanComparisonChart.pdf, [accessed March 29, 2015].

Also see the following for a discussion of the new NC403(b) plan https://www.nctreasurer.com/Retirement-and-Savings/Managing-My-Retirement/Pages/NC-403b-Pro gram.aspx, [accessed March 29, 2015].

${ }^{45}$ IRS discussion of 403(b) plans can be found at: http://www.irs.gov/publications/p571/index.html, [accessed March 29, 2015] and at:

http://www.irs.gov/Retirement-Plans/Retirement-Plans-FAQs-regarding-403(b)-Tax-Sheltered-Annuit y-Plans, , [accessed March 29, 2015].

Readers may also find the Department of Labor's discussion of 403(b) interesting: 
allow employees to make pre-tax contributions; however, government employers can also offer Roth options in the various plans.

Historically, 403(b) plans were the primary option selected by school districts. Prior to the passage of the Economic Growth and Tax Relief Reconciliation Act in 2001, 401(k), 403(b) and 457 plans were subject to difference regulations related to elective deferrals, employer contributions and other areas. After the passage of new legislation, 403(b) plans were subject to greater oversight.

Two important distinctions exist between 401(k)/403(b) and 457 plans. The annual dollar limit on employee contributions is the same in all of the plans, $\$ 18,000$ in 2015 , and this maximum is typically increased annually. Importantly, contributions to 401(k) and 403(b) plans count toward the same maximum contribution limit; however, contributions to 457 plans are viewed independently from the other two plans. Second, distributions without tax penalties are allowed at retirement after age 55 in both the 401(k) and 403(b) plans while the 457 plans allow such distributions at termination of employment at any age. In service distributions are allowed prior to age 59 and a half in both the $401(\mathrm{k})$ and 403(b) plans with a 10 percent tax penalty. In service distributions are not allowed in 457 plans.

http://www.dol.gov/ebsa/regs/fab2010-1.html, [accessed March 29, 2015].

The California Teachers association provides a useful comparison of all three types of plans, http://ctainvest.org/home/403b-457-Plans/403b-457-overview/comparing-401k-403b-457-plans.aspx, [accessed March 29, 2015]. 
All of the plans have age 50 and over catch-up provisions, but the policies are slightly different. All of the plans have a required minimum distribution at age 70 and a half. All distributions in each of the non-Roth plans are treated as ordinary income for federal income tax purposes. All of the plans allow rollovers to other retirement saving plans or IRAs. 


\section{APPENDIX B \\ Simulations of Variation in Supplemental Plan Participation}

In our econometric framework, we consider the effect of individual and district

characteristics on the choice to participate in a supplemental retirement saving plan.

True model:

(1) $\operatorname{Pr}\left(\right.$ Participation $\left._{i}=1\right)=\Phi\left(X_{i j} \beta+\delta_{j}\right)$

Note that the 'true model' represented in equation (1) suggests that the average effect of individual characteristics $(\beta)$ is not a function of district characteristics (as would yield a random coefficients type model). To better quantify the amount of variation across districts, we construct two measures of observed variation. For this exercise, we do not include district effects and simulate random assignment to districts both with and without adjusting for individual characteristics. We calculate the residual by subtracting the predicted likelihood of participating from the observed data and define hat $\left(\varepsilon_{\mathrm{ij}}\right)$ to be the regression-predicted residual when individual characteristics are included in the regression model.

First, we assign each individual to their own district and calculate the 'unadjusted' participation rate. We calculate the unadjusted participation:

- $\quad 90^{\text {th }}$ percentile participation rate is $47.0 \%$

- $10^{\text {th }}$ percentile participation rates is $21.6 \%$

- $\quad$ 90-10 Range: yielding a 25.2 percentage point difference 
Next, we instead use the regression adjusted participation rate in the district (equal to the mean of hat $\left(\varepsilon_{\mathrm{ij}}\right)$ within the district). We calculate the adjusted participation:

- $\quad 90^{\text {th }}$ percentile participation rate is $14.2 \%$

- $\quad 10^{\text {th }}$ percentile participation rates is $-11.5 \%$

- $\quad$ 90-10 Range: yielding a 25.6 percentage point difference

SIMULATION 1: The 'unadjusted' spread is calculated by randomly assigning individuals to districts. We calculate the difference between the $90^{\text {th }}$ and $10^{\text {th }}$ percentile in participation rates, the '90-10 Range'. We repeat the simulation 1,000 times and plot the resulting 90-10 Ranges.

The distribution is approximately normal with a low mean of 0.052 (Std Dev. 0.008).

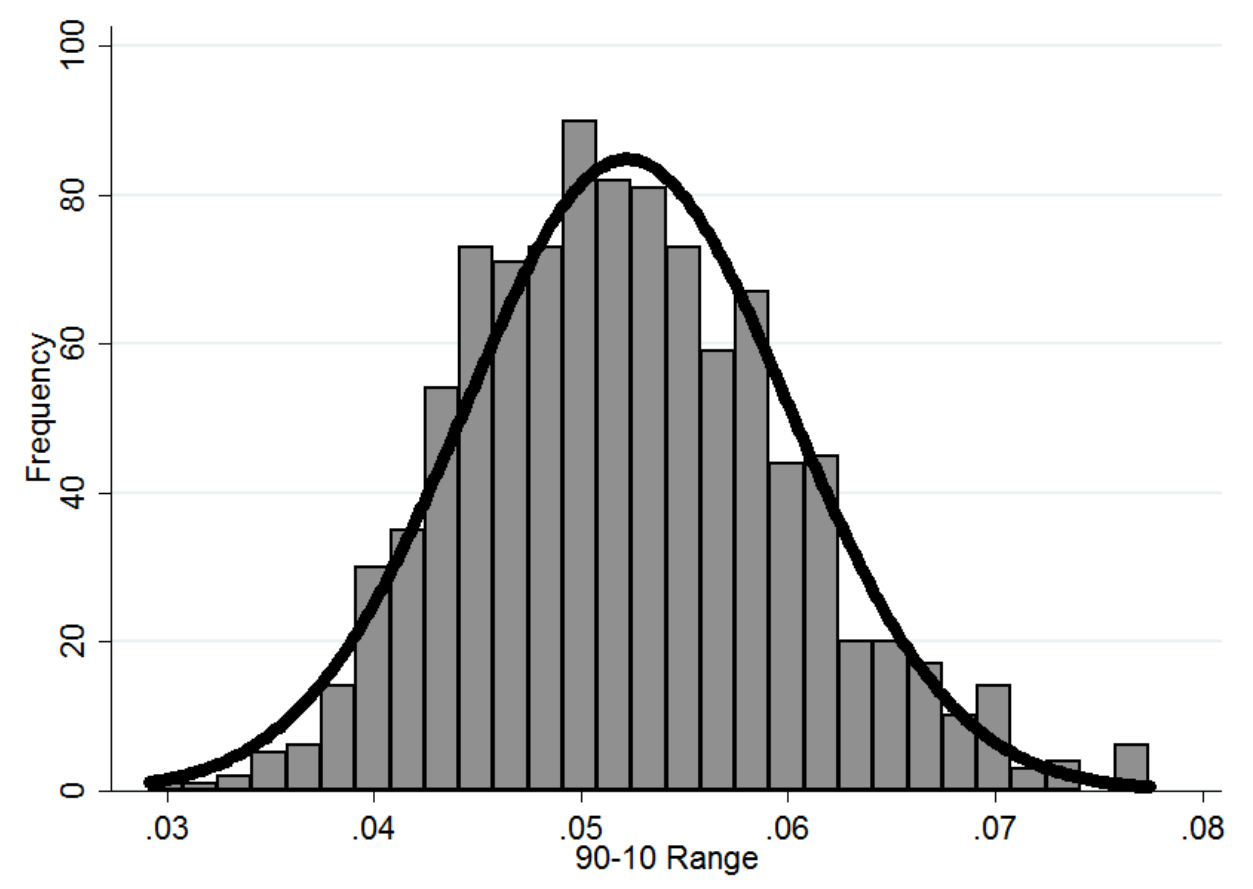


SIMULATION 2: We calculate the regression-adjusted residual (hat $\left.\left(\varepsilon_{\mathrm{ij}}\right)\right)$ for each individual. Then, we randomly assign individuals to districts and calculate the difference between the $90^{\text {th }}$ and $10^{\text {th }}$ percentile in participation rates, the '90-10 Range'. We repeat the simulation 1,000 times and plot the resulting 90-10 Ranges. The distribution is approximately normal with a low mean of 0.050 (std. dev. 0.007).

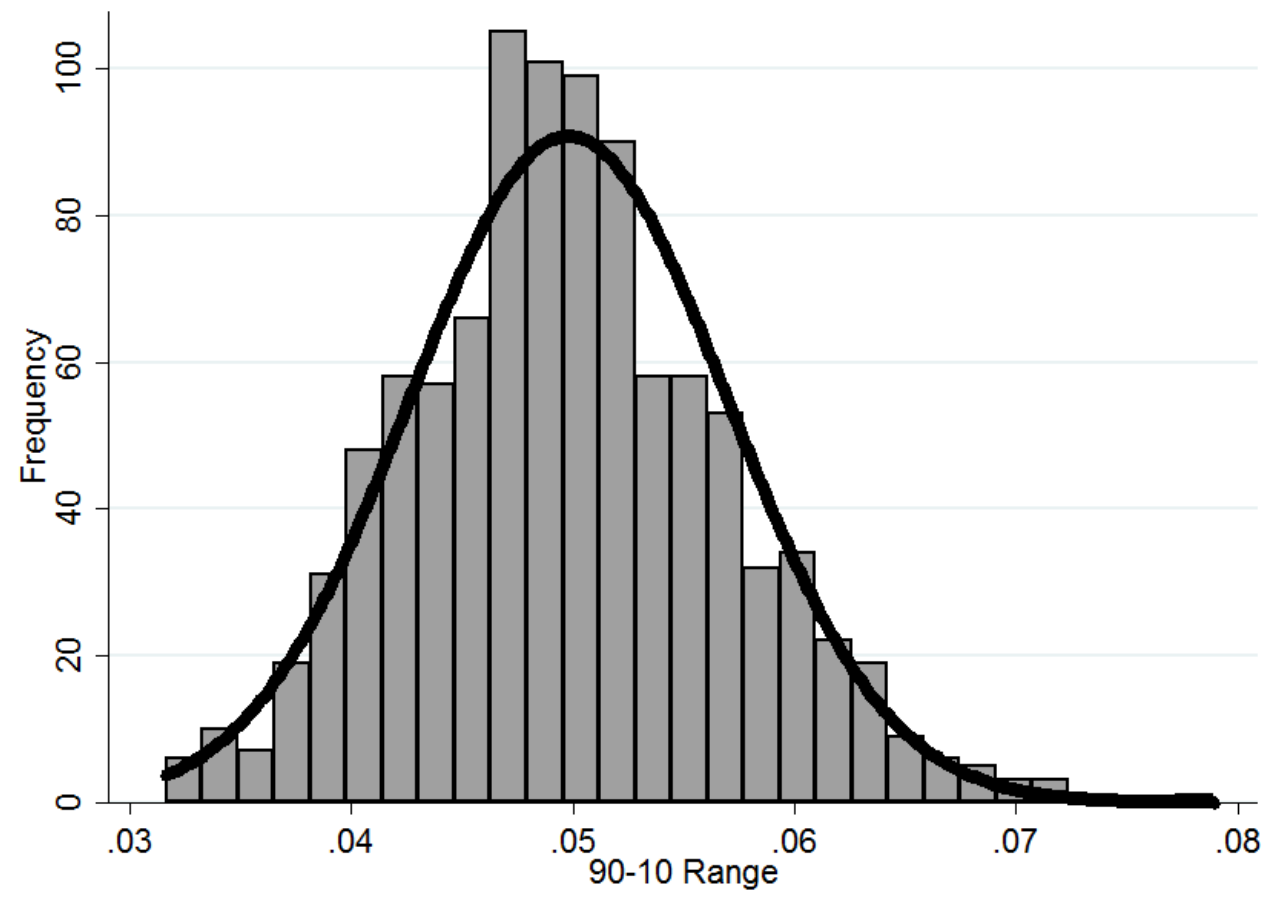

CONCLUSION: The observed 90-10 spread of 25 percentage points is far outside the region of what would be expected from random variation. 
APPENDIX C

Supplemental Tables

Appendix Page 7 
Table C1: Means and Sample Descriptive Statistics

\begin{tabular}{|c|c|}
\hline School Districts & 53 \\
\hline Number of Individuals & 71,156 \\
\hline Age below 35 & $20.61 \%$ \\
\hline Age 35-49.99 & $39.57 \%$ \\
\hline Age 50-54.99 & $14.65 \%$ \\
\hline Age $55+$ & $25.16 \%$ \\
\hline Annual Salary & $\$ 34,623$ \\
\hline Superintendents & $0.07 \%$ \\
\hline Managers & $3.07 \%$ \\
\hline Instructional & $78.59 \%$ \\
\hline Support & $18.30 \%$ \\
\hline White & $72.90 \%$ \\
\hline Black & $20.61 \%$ \\
\hline Hispanic & $1.41 \%$ \\
\hline Other & $5.08 \%$ \\
\hline \multicolumn{2}{|l|}{ Tenure $^{\mathrm{b}}$} \\
\hline Less than 1 & $7.71 \%$ \\
\hline $1-2.99$ & $10.01 \%$ \\
\hline $3-4.99$ & $8.75 \%$ \\
\hline $5-10.99$ & $29.21 \%$ \\
\hline $11-20.99$ & $29.61 \%$ \\
\hline 21 or more & $14.63 \%$ \\
\hline
\end{tabular}


Table C.2: Plan Participation and District Characteristics for Recent Hires

403(b) Plan

Any Plan 403(b) Plan Participation

(1)

Plan Offerings:

3-5 vendors

6 or more vendors

Offers NC 457

Offers Local 457

Adopted NC 457 w/in 5 yrs

District Oversight:

Selective

Evaluate plan offerings

Criteria reviewed w/in 5 years

District Information Provision:

Moderate quality website

High quality website

Directly Provide Information

District Size (in 00s)



(2)

0.010

$(0.016)$

0.014

$(0.014)$

$0.040^{*}$

$(0.022)$

$-0.001$

$(0.013)$

$-0.007$

(0.015)
$(0.032)$

0.026

$(0.025)$

0.009

$(0.029)$

$-0.001$

$(0.025)$

$-0.042$

$(0.029)$

$-0.012$

$(0.022)$

$0.108^{* * *}$

(0.033)

$0.054 *$

$(0.031)$

$0.043^{* *}$

(0.019)

$-0.002 * * *$

(0.001)
$-0.023 *$

$(0.013)$

$-0.023 *$

(0.014)

$0.029 * *$

(0.013)

$0.037^{* *}$

(0.015)

0.006

(0.018)

$0.021^{* *}$

(0.009)

$-0.001$

(0.000)
(3)

$-0.011$

$(0.107)$

$-0.013$

(0.125)

0.160

(0.110)

$-0.187^{*}$

(0.109)

$-0.146$

(0.095)

$-0.230^{* *}$

(0.091)

$-0.067$

(0.098)

$0.271 * * *$

(0.094)

Observations

9,174

9,174

$-0.068$

(0.092)

$-0.029$

(0.119)

0.039

$(0.100)$

Mean Dependent Variable

0.1131

0.0455

$0.009 * * *$

(0.003)

Notes: Data are from payroll records merged with district survey responses. The sample is restricted to individuals hired within the two years prior to data collection (2011-2012.) All models include individual characteristics reported in Table 3 but exclude district fixed effects. Marginal effects, calculated at the mean, are estimated from Probit regressions. Robust standard errors are in parentheses and are clustered at the district level. *** $\mathrm{p}<0.01, * * \mathrm{p}<0.05, * \mathrm{p}<0.1$. 